\title{
C Review
}

Volume 280

136th Year of Publication JANUARY 2002

No. 1632

$£ 3.25$

FAITH, FANATICISM AND FOOD IN ISLAM Roger Kershaw

ETHNIC GROUPS AND NATIONAL UNITY IN AFGHANISTAN

Hafizullah Emadi

AUSTRALIA: FEAR AND LOATHING ON THE CAMPAIGN TRAIL Keith Suter

BELARUS UNDER LUKASHENKO Igor PopOV

LORD LONGFORD: A CRUSADING PEER Jonathan W. Doering

WAR LEAVES A SHADOW OF HUNGER OVER ERITREA

Donica Tesfamariam

AMY LEVY: A TRAGIC VICTORIAN NOVELIST Richard Whittington-Egan

WITH SIXTEEN PAGES OF REVIEWS 


\section{Contemporary Review}

Founded 1866

incorporating The Fortnightly

No. 1632

Faith, Fanaticism and Food in Islam

Ethnic Groups and National Unity in Afghanistan

Australia: Fear and Loathing on the Campaign Trail

Poems: Parkbenchers Epitaph for an Auctioneer

Belarus under Lukashenko

Poem: Durham Cathedral

Lord Longford: A Crusading Peer

War Leaves a Shadow of Hunger over Eritrea

Amy Levy: A Tragic Victorian Novelist

A Letter from Auschwitz to My Daughters

Roger Kershaw 1

Hafizullah Emadi $\quad 8$

Keith Suter

16

Tim Hopkins

Igor Popov

A. K. Whitehead

Jonathan W. Doering

31

Donica Tesfamariam

Richard Whittington-Egan

Charles Foster

\section{REVIEWS}

Peter Hylarides, R. D. Kernohan, Robert S. Redmond,

Richard Whittington-Egan, Michael Karwowski, Geoffrey Heptonstall

New and Noteworthy

The World of Paperbacks $\quad 57$

Short Reviews

Éditor:

DR. RICHARD MULLEN

Literary Editor:

DR. JAMES MUNSON
Editorial Advisors:

PROFESSOR ESMOND WRIGHT

ROBIN FINDLAY

JAMES LOGERFO
Art Correspondent:

DONALD BRUCE

Managing Editor: Dr. Alex KerR

Associate Editor:

AnSELMa BRUCE

(C) 2002. CONTEMPORARY REVIEW (ISSN/0010/7565) is published monthly by the Contemporary Review Co. Ltd., PO Box 1242, Oxford OX1 4FJ, England. The Editor is pleased to receive unsolicited articles. If authors wish any manuscript to be returned it must be accompanied by a stamped addressed envelope or the requisite amount in International Postal Reply Coupons. Printed by Alden Press, Osney Mead, Oxford OX2 OEF.

U.S. Mailing Agent: Mercury Airfreight International Inc., 365 Blair Road, Avenel, NJ 07001. Annual Subscription price (including postage): U.K. $£ 44.00$, U.S.A. and Canada $\$ 176.00$. Periodicals Postage Paid at Rahway NJ. Rates for all other countries on application. Copies can be sent by airmail outside U.S. and Canada: extra costs given on request.

U.S. POSTMASTER: Please send all address corrections to Contemporary Review, c/o Mercury Airfreight International Inc., 365 Blair Road, Avenel, NJ 07001. 


\section{ETHNIC GROUPS AND NATIONAL UNITY IN AFGHANISTAN}

\section{Hafizullah Emadi}

$\mathrm{K}$ ARL von Clausewitz wrote that war is nothing but the pursuit of politics by other means. The war in Afghanistan could be characterized as concerted efforts by ethnic communities to jockey for power in the post-Soviet era. One of the chief characteristics of the rogue political parties and radicalized faith-based groups leading this war is a lack of tolerance for other faiths and political beliefs. Monopolization of institutions of power by one political and ethnic group, its unwillingness to transcend narrow sectarian interests for the common good and the lack of dialogue among warring factions inhibited the resolution of ethnic and tribal conflicts. Since the objective of this lengthy civil war is power and position, its effective resolution lies in the distribution of power and institutions of power among ethnic communities and participation in the country's politics that previous despotic regimes denied them.

\section{Ethnic and Religious Communities}

Afghanistan's history is replete with violence, tribal and ethnic conflicts resulting in the domination of the country's politics by one ethno-religious community whose leadership excluded others from the decision-making processes. Those in a leadership position did not consider the country's multiplicity of languages, faiths, cultures, traditions and ethnic communities as a source of strength but as a weakness and consequently tried to suppress individualism and aspirations of other ethnic communities for autonomy. An authoritarian-top-down development approach paved the way for periodic conflicts between the dominant and the dominated ethnic communities that hampered the building of a modern and united civil society. Afghanistan is a multi-lingual and multi-ethnic community. It is estimated that some forty-nine languages are spoken of which Persian (Farsi) and Pushtu are the two officially recognized languages; more than fifty per cent of the country's population speak Persian. The country is also divided along ethnic lines. Pushtuns are the dominant ethnic group making up about 38 per cent of the population, followed by Tajiks ( 25 per cent), Hazaras (19 per cent), Uzbeks (6 per cent) and many other ethnic communities such as Turkman, Baluch, Aimaq, Qirghiz, Nuristani, Arab, Hindu and others. All the ethnic communities have their unique traditions and cultures and, to some extent, have participated equally in the country's political, social, and economic development; however, the word Afghani is often associated with the Pushtuns, whose name also translates to Afghan. In ancient times the country was called Aryana and later Khurasan, the land of the rising sun, when the Islamic Empire extended its rule over the region. By mid-eighteenth century this region formed the basis of modern Afghanistan. The word Afghanistan literally means homeland of the Afghans and the word Afghan has been applied to all ethnic communities that reside in the country. However, other ethnic communities do not call themselves 
by such a designation but identify themselves by their respective ethnic name such as Tajik, Hazara, Baluch, etc.

Afghanistan is further fragmented along sectarian lines. It is estimated that at least seventy-five per cent of the population subscribe to the legal schools of the Sunni branch of Islam. Twenty-four per cent practise the Shia faith of Islam (Ithna Ashari and Ismaeilis) while less than one per cent are followers of other faiths, i.e. Hindus, Sikhs and Jews. In addition to this diversity the country is also divided on the basis of tribalism and regionalism.

Ever since the rise to power of Ahmad Shah Abdali in 1747, the head of state has always been a member of one of the prominent Sunni Pushtun tribal communities, i.e., Sadozai, Barakzai and Mohammadzai. Other Sunni Pushtun tribes and clans occupied junior positions in the state apparatuses, followed in turn by dominant Persian speaking communities. The Shiite Hazara community sat at the bottom of Afghanistan's political and social ladder. For brief periods in 1929 and 1992-96 the Pushtuns lost power to the Tajiks but the latter failed to maintain their rule each time they seized power.

\section{Repression and Ethnic Tension}

Tribal structure remained intact in Afghanistan. The tribal chiefs of each ethnic community enjoyed some degree of internal autonomy, but fought the central authority whenever it tried to interfere in their internal affairs. Tribal chiefs had always used sectarian differences to advance their own cause. Ethnic and religious bigotry reached its height during Amir Abd al-Rahman's rule (1880-1901), when he sent several expeditions to the central and northern regions of the country in an attempt to subjugate non-Pushtun tribal chiefs and other independent power centres to his rule. Abd al-Rahman's military offensive on the Hazarajat led to the massacre of thousands of Hazaras, the displacement of thousands who were not killed to neighbouring countries and the subsequent enslavement of the remainder. Abd al-Rahman justified his war on the Hazaras on the grounds that the Hazaras were kafir, infidels, and incited the Sunnis to raid Hazara villages and towns. Abd al-Rahman reminded his subjects to be thankful to him for enslaving the Hazaras and not them, for otherwise they would have had to work like donkeys if it were not that the enslaved donkeys of Hazaras do all the work for them.

By sending Sunni clerics to Hazara regions, Abd al-Rahman forced the Hazaras to abandon Shiism and pray in the Sunni mosques. However, the Hazaras adhered to their faith by maintaining taqiyya, dissimulation of one's faith in a hostile environment.

Subsequent Pushtun dominated governments since the downfall of Amanullah's rule (1919-1929) neither devised policies to promote the welfare of other ethnic communities nor did they allocate funds to develop infrastructures in the peripheral regions inhabited by non-Pushtun communities. This development policy contributed to the persistence of tribalism, regionalism and conflict among ethnic communities. The struggle for change and political reform 
intensified in the immediate post-World War II period, as evidenced by the formation of several liberal and progressive political groups representing the interests of the poor and marginalized communities. The dominant class maintained its rule by heavy reliance on the standing army buttressed by the creation of a new ideology - Afghan nationalism - and efforts were made to rally non-Pushtun communities behind this ideology. Formulation of this ideology resulted in the propagation of the Pushtu language and culture (the state established Pushtu language classes forcing civil service employees to attend these classes) and suppression of other cultures and languages.

In the 1960s and early 1970s new political groups emerged trying to alter the status quo. These groups advocated ideologies such as nationalism, socialism and a return to an Islamic way of life. The polarization of the country's politics led to the downfall of the monarchy headed by Mohammad Zahir (1933-73) and the establishment, in 1973, of a republican regime under the leadership of Zahir's nephew, former Premier Mohammad Daoud. The republican regime circumvented the issue of equality of ethnic communities by creating a new political party, Hizb-e-Enqilab-e-Milli, National Revolutionary Party. The party was depicted as an institution that represented and defended the interests of all ethnic communities, in reality it remained an instrument of the personal power of the President who was intent on retaining his position. Such a policy led to increasing polarization of the society causing the subjugated ethnic communities to despise the new order. The regime was overthrown during the 1978 April coup, which was carried out by army officers loyal to Khalq and Parcham factions of the pro-Soviet People's Democratic Party of Afghanistan (PDPA).

The top leaders of the Khalq faction, Noor Mohammad Taraki and his deputy and successor, Hafizullah Amin, were Pushtun, as were the majority of the party's rank and file members; the members of the Parcham faction, on the other hand, were mainly royalists from the Persian speaking communities. The PDPA's policy concerning the equality of ethnic communities did not go beyond the established rhetoric about fraternity among the national communities. It excluded opposition groups from the institutions of power in its drive to build a Khalqi vision of a socialist society where one million Khalqi is enough and the rest must be eliminated. Such a policy backfired because it incited the ethnic and religious groups and political parties to oppose the regime.

The Soviet Union deployed a contingent of the Red Army to Afghanistan in December 1979 to support the client regime and installed Babrak Karmal as a new puppet ruler. The Soviet occupation prompted all ethno-linguistic communities to fight the invaders. Having failed to maintain their colonial occupation of Afghanistan, the Soviets were forced to withdraw their troops in February 1989. However the puppet regime of Najibullah continued to maintain its rule with active Soviet support for a few more years. During their rule the Khalqis and Parchamis tortured and executed thousands of revolutionaries, progressive, patriotic, democratic and liberal forces, denouncing them as 'hired agents of imperialism' and branding Western countries as 'bloodthirsty imperialist' powers. 


\section{Islamic Resurgence and Jihad}

During the Soviet occupation, anti-Soviet insurgents remained divided along sectarian lines. The Shiite political parties, whose rank and file supporters were mainly Hazaras, relied on Iran for financial and political support. Islamic parties of Sunni orientation were supported by Pakistan, the conservative countries of the Middle East, Europe and the United States. Pakistan's Inter Service Intelligence agency, the ISI, distributed international aid exclusively to these Sunni Islamic parties. Pakistan and Iran actively meddled in Afghanistan's politics in an effort to influence the direction of transformation through their client parties. Saudi Arabia also engaged in Afghanistan's politics by promoting its own brand of Islam, Wahhabism. To this end the Saudi leadership, working in close collaboration with the CIA, sent the Saudi millionaire Osama bin Laden to organize the poor and Islamic fundamentalists from various Islamic countries to join the war in Afghanistan, and provided these groups with food and financial support. In so doing the Saudis' main objective was also to thwart the political struggle against their own kingdom and other conservative regimes in the Middle East. When the Russian puppet regime collapsed in 1992, these 'Afghan Arabs' found that they were not welcome back home; instead the theocratic regime in Afghanistan headed by Rabbani granted them citizenship.

After the Soviet troop withdrawal from Afghanistan, the PDPA, which subsequently renamed itself Hizb-e-Watan, Party of the Homeland, experienced disunity within the Parcham and Khalq factions and mounting ethnic tensions in the regime. The regime's erstwhile supporter, the Uzbek warlord Abdul Rashid Dostam, formed his own group, Junbish-e-Milli-Islami, National Islamic Movement, and forged a convenient alliance with the Tajik warlord, Ahmad Shah Masoud. Most hard-line Pushtun elements of the Khalq allied with their counterparts in Hizb-e-Islami, Islamic Party under Hikmatyar, to prevent Dostam and Masoud from seizing Kabul. As a result of this internal struggle the Kabul regime collapsed and an Islamic state under the leadership of Sebghatullah Mojaddadi, head of Jabha-e-MilliieiNijat, National Islamic Front, was established in Kabul in April 1992. Mojaddadi's rule was short. He was succeeded on 30 August 1992 by Burhanuddin Rabbani, a Tajik from the Badakhshan and head of Jamiat-e-Islami, Islamic Society. The Khalq and Parcham fell from grace soon after the transfer of power and their leaders sought refuge in the West, which they now embraced as a true bastion of democracy that defends and protects human rights and individual freedom.

People in Afghanistan welcomed the downfall of the Russian puppet regime and expected that the theocratic regime would facilitate greater participation of diverse ethnic communities in local and state politics. However, the Islamic regime's perception of national unity was based on the negation of the multiplicity of the country's faith, culture and ethnic composition. By employing new terminology such as Millat-e-Islam, Muslim Nation, Millat-e-Mujahid, Nation of Holy Warriors, etc., the theocratic regime tried to circumvent the issue of equality among ethnic communities confident that such an approach would 
resolve contradictions among tribal and ethnic communities. But its policy proved to be as fatally wrong as the previous attempts by despotic rulers who tried to unite ethnic and religious communities by building 'Afghan nationalism', not realizing that national unity cannot be attained by the negation of ethnic communities but by their recognition. The theocratic regime, which struggled for control of Afghanistan, was divided into several major groups.

Forces under the ruling fundamentalist party of Jamiat-e-Islami of Rabbani and his defence minister Masoud were mostly Tajiks with a few supporters from other ethnic communities. The party's major ally, Junbish-e-Milli-e-Islami of Dostam was primarily Uzbek with a few other smaller ethnic groups. Other contenders for power were: Harakat-e-Islami, Islamic Movement, a small Shiite group headed by Asif Mohsini, the two fundamentalist parties of Hizb-e-Islami of Hikmatyar and Ittihad-e-Islami, Islamic Unity of Abd al-Rab Rasul Sayyaf, who are mainly Sunni Pushtuns in their rank and file. Leaders and supporters of Hizb-e-Wahdat, Unity Party, are mainly Hazaras of Shiite orientation.

The theocratic regime failed to restore peace and could not devise a comprehensive development strategy to facilitate Afghanistan's transition into the new millennium. Its policy of building an Islamic society did not go beyond mandating men to wear beards and women to wear Islamic dress, the chadari, that cover their bodies from head to toe. Armed conflicts among the rogue parties for power not only destroyed the country's infrastructure but also claimed the lives of an estimated 25,000 to 30,000 innocent men, women and children in Kabul alone. Armed gunmen belonging to various warring factions abducted and raped women of rival ethnic communities and then killed them in order to cover up their acts. They used rape as a means to dishonour the entire rival group and community and to threaten them if they dared to oppose their rule. Between 1992-96 a large number of Shiite Hazaras were massacred by forces loyal to Rabbani and Masoud, and a number of Hazara women were abducted in order to be sold into prostitution or to be given as gifts to financial supporters.

\section{The Taliban Phenomenon}

In the summer of 1994 an ultra fundamentalist group emerged, the Taliban (the word literally means students of religious studies). They are Sunni Pushtun with their own interpretation and understanding of Islamic faith. The Taliban seized Kandahar in October that year and by September 1995 they had launched a blitzkrieg on Herat, forcing Ismail Khan, the commander of the province, an ally of Rabbani, who had lost public support, to flee to Iran. By 1996 the Taliban conquered more territories in the southeastern region of Afghanistan and advanced toward Kabul. Rabbani and Masoud, despised by the residents of Kabul, evacuated their forces and retreated to the northern part of the country, the Panjshir valley and Badakhshan province. The Taliban's victory forced the defeated warlords of the Tajik, Hazara and Uzbek communities as well as a few smaller Pushtun groups to forge a new alliance known as the Northern Alliance to counter the Taliban's growing military threat. After consolidating 
their power base in Kabul the Taliban embarked upon a war of conquest, seizing more territories from their opponents, the Hazaras in central and the Uzbkes in the northern parts of the country.

The war weary residents of the country that had suffered enormous casualties and humiliation under former warlords initially welcomed the Taliban, whose political rhetoric centered on restoration of peace and on ridding the country of factional war. However, people's hopes were shattered when the Taliban instituted draconian administrative measures, depriving citizens of their basic rights and liberties as they set about building a pure Islamic society: forbidding women to work outside the home and attend schools; sentencing to death those who committed acts of sexual impropriety; amputating a person's hand for stealing; etc. The Taliban policy toward non-Pushtun communities was reprehensible. After defeating them the Taliban destroyed their houses and properties in a crude attempt at collective punishment. The Taliban regarded the Shiite Hazaras as infidels and declared a holy war on them. To cite one instance, when they defeated the supporters of Hizb-e-Wahdat in Mazar-e-Sharif, the Taliban's appointed governor, Mullah Mamoon Niazi, stated that 'Hazaras are not Muslims, they are Shia, they are kafir, infidel. Wherever you go we will catch you. If you go up, we will pull you down by your feet, and if you hide below, we will pull you up by your hair'.

The Taliban's repressive policies led to their increasing isolation and widespread condemnation from the international community. This situation presented the defeated warlords of the Northern Alliance with the opportunity to present themselves as champions of human rights and women's rights, that they themselves had abused when they were in power. The Northern Alliance suffered a setback when two Arab suicide bombers posing as journalists killed their military commander, Masoud, on 9 September 2001 (rumors abounded that Rabbani had a hand in the conspiracy). The United States, which had supported the Islamic fundamentalists during the Soviet occupation and had celebrated the Soviet defeat in Afghanistan, did little to stop the ferocious cycle of ethnic cleansing in the post-Soviet era. In the beginning, it believed naively that the rise of the Taliban represented a positive development, and a means to use a stable Afghanistan as a stepping stone to gain access to natural resources in the Caspian Sea as well as the markets and resources of the newly independent republics of Central Asia.

However, when the Taliban provided shelter to Osama bin Laden, the United States reversed its attitude toward the Taliban and denounced them as a rogue administration. The US accused Bin Laden and his supporters of responsibility for the bombing of its embassies in Kenya and Tanzania on 7 August 1998 and the assault on the US warship, the USS Cole in Yemen on 12 October 2000. It condemned Bin Laden and his al-Qaeda, the Base, terrorist network for hijacking four US commercial planes that were used as weapons of mass destruction in the attack on the World Trade Center buildings in New York and the Pentagon in Washington D.C. on 11 September 2001. The US subsequently declared a 'war 
on terrorism' and the Taliban for harbouring terrorists and providing them with training facilities in territory under their control. Britain soon showed itelf to be America's closest ally by joining in the war. US warplanes, aided by Britain, began bombing Taliban controlled areas on 7 October 2001. The US declared that it would continue the war until the Taliban was overthrown and a new broadbased government established in Kabul. To this end the US announced its support for the ousted warlords in the north and approached former commanders like Abdul Haq to mobilize anti-Taliban rebellion (he was captured and executed by the Taliban in late October 2001) as well as for efforts by former King Zahir, exiled in Rome, to overthrow the Taliban.

Increased US bombing weakened the Taliban and aided the Northern Alliance in their drive to defeat the Taliban. The Northern Alliance captured several cities in the north as well as the capital, Kabul on 13 November 2001 and their advancing armies executed Taliban fighters in their wake. The Taliban fled Kabul and retreated to the southern part of the country. Residents of Kabul who suffered enormously under the Taliban and the Northern Alliance now cautiously welcomed the Northern Alliance again. Marking the occasion not only with celebratory gunfire but also with newly trimmed beards. The Western governments arranged a conference of various Afghan groups to meet in Bonn, Germany at the end of November. If the international community abandons the situation once again prior to any peace formula achieved this will herald the inevitable bloodbath as ethnic vengeance and hatreds suffuse the land again.

\section{Strategies for Peace and Reconstruction}

There are two types of thinking regarding post-Taliban administration in Afghanistan. Policy makers in the US support the creation of a new government that includes the Northern Alliance and moderate elements of the Taliban. The other mode of thinking supported by Afghanistani technocrats centres on the concept of convening a Loya Jirgah, Grand Assembly of Tribal Chiefs, to elect the head of a transitional government. The underlying assumptions of both strategies consist in the revival of a political mechanism that is based on tribal aristocracy. These mechanisms are touted as the only conflict resolution mechanism to solve the new problem of great social, political and cultural magnitude, and whose main objective is the deconstruction of the tribal aristocracy and domination of one ethnic community over others. These strategies promote a hierarchical political system from the top without substantially altering the status quo. Their proposed remedies do not lead to the creation of a genuine representative government because under the present condition where the warlords rule by guns, the citizens of Afghanistan would not be able to cast a free vote for a representative of their choice, only those endorsed by the warlords. A system based on this political facade will not eliminate tribal aristocracy nor will it provide an opportunity for free public participation in decision-making both at local and national levels in the state bureaucracy.

A more viable solution that promises to lead to a stable Afghanistan is to 
adopt a grass-roots approach to rebuilding civic and state institutions by supporting Village Committees where village members elect one of their members as head of the committee in charge of policy making in their respective villages. The structure of the Villages Committees could be extended at the district level where a Village District Committee would represent a cluster of villages; and the Village District Committees could be extended at the provincial level. When such a mechanism is in place throughout the country, the head of each provincial committee could then contend in a general election. The person who gains the majority of public votes must be recognized and supported as the new head of the state. (For details see, Hafizullah Emadi, 'Rebuilding Afghanistan', Contemporary Review, April 2001.)

The country's reconstruction is possible only through pluralistic institutions. A federal type of political arrangement embodies the will of the people and corresponds to the realities of Afghanistan's diversity and ethnic composition. Under the federal type of political arrangement regions inhabited by a particular ethnic community will enjoy autonomy in the domestic arena but remain under the leadership of the federal state in matters of national security and national defence. This development will take place if international peacekeeping forces, or peacekeeping forces by neutral Islamic countries, are deployed in Afghanistan under the auspices of the United Nations to maintain law and order, thereby enabling the people of Afghanistan to lay the foundation of a broad-based representative government.

One of the immediate tasks of a new government and the international community will be bringing war criminals to justice. All ethnic communities have been equally brutalized and lost loved ones under the brutal rule of various warlords and heads of rogue political groups. It is not easy for the victims to simply ignore their grievances and forgive these warlords and work toward national reconciliation. Bringing war criminals to justice strengthens people's faith in justice, facilitates the process of national reconciliation and motivates them to work together to rebuild their society. Otherwise people are likely to resort to acts of vengeance and take matters into their own hands in dispensing justice.

Former King Zahir continues to possess influence and could use it to facilitate public efforts in the creation of a new political institution that represents the interests of the diverse ethnic communities. In the beginning the process will be difficult and slow, but a government based on federalism will be able to sustain and facilitate Afghanistan's transition into the world community and put it on a path toward productive growth and peaceful development, as Sultan Mohammad Shah, the Aga Khan III, said eloquently: 'Not chaos-like together crushed and bruised, /But, like the world, harmoniously defused, /Where order in variety we see, /And where, though all may differ, all agree'.

Hafizullah Emadi is an Afghanistan-born writer and development consultant now in the USA. 